\title{
Factors Influencing Tax Avoidance Activity: An Empirical Study from Indonesia Stock Exchange
}

\author{
Vinny Jingga and Lina Lina* \\ University of Pelita Harapan, Indonesia
}

\begin{abstract}
This research aims to examine the influence of the firm characteristics to tax avoidance activity in the listed companies in Indonesia. This research uses the proxies of firm size, leverage, capital intensity, inventory intensity as the firm characteristics and return on asset and marketto-book ratio as control variables. The samples of this research consist of 158 firm-year observations from all industries which are listed in Indonesia Stock Exchange during 2010-2013. The samples are selected by using purposive sampling method through several specific sample criteria. The technique used to examine hypothesis is multiple regression analysis. The result of this research reveals that leverage has a positive influence towards tax avoidance activity, while the rest variables have no influence towards tax avoidance activity.
\end{abstract}

Keywords: Firm characteristics, tax avoidance activities, return on asset, market-to-book ratio

JEL Classification: M4, M40, M41, M42, M48, M49

Paper Type: Research

\section{INTRODUCTION}

The growth and development process of a country is a process of continuous renewal to reach a condition that is considered as a proper condition for the living of its citizens. For Indonesian government, the goal is to achieve the national goals as stated in the Constitution of the Republic of Indonesia year 1945, which are to create prosperity and welfare of the people. In an effort to achieve the national goals, all parties are involved in implementing the development in all fields to improve, develop, and utilize the available resources. The development is carried out through a series of investments that can only be done with great financial support. The development funds can be obtained from a variety of sources, either public or private, both from local and abroad. One of the sources of these funds is taxes.

Tax contributions in recent years are increasing significantly and accounted as the most influential financing source in purpose to implement the national development programs that will gradually increase the economic growth and prosperity of the nation

* Corresponding author: E-mail: lina.fe@uph.edu, Phone: +628993618885 
(Pohan, 2013). Tax in a company gains significant attention as the amount of tax depends on the amount of income generated by the company in which the greater the income earned, the greater the tax to be paid. For companies, the tax is a burden that will reduce the amount of net income received by the company then the company will carry out any methods to be able to pay taxes as low as possible. In contrast, the government treats the tax as one of the primary sources of the state revenues and the government will conduct any ways to collect taxes as high as possible. The difference in views between the government and the management of the company in respect of taxes causes many companies when getting a high tax burden; they are encouraged to overcome them through effective tax planning (Priantara, 2011). The method that can be done is to minimize the tax burden within the limits of the tax regulations. Therefore, companies need the right tax planning to pay taxes efficiently.

As used in this paper, the term 'tax avoidance' includes any tax planning method that taxpayers use to legally reduce their income tax payments. For purposes of this article, tax evasion such as reporting incomes below the actual and reporting high-level of reduction is not considered as "tax avoidance." Kirchler, Maciejovsky, and Schneider (2003) state that tax avoidance refers to the reduction of tax payments in a legal way, for instance through the loopholes of existing tax laws. Effective tax planning reduces the present value of tax payments and increases the after-tax rate of return to investors in a firm.

This paper extends the literature review by reconciling prior research (Lestari, 2010; Surbakti, 2012) on whether the factors that affect the effective tax rates (ETRs) such as the firm characteristics also have a direct relationship to tax avoidance engaged by the company. This recognizes the ETRs, and discretionary measures of tax avoidance as the proxies that can be used to measure tax avoidance, according to the explanation by Hanlon and Heitzman (2010). The lack of research evidence on the relation between the firm characteristics (firm size, leverage, and asset mix) to the tax avoidance activities engaged by the companies particularly in a broad sample of all listed companies in the capital market makes some contribution to this study.

The following are the research questions: 1). Does firm size influence tax avoidance activity? 2). Does leverage influence tax avoidance activity? 3). Does asset mix influence tax avoidance activity? The objective of this research is to provide empirical evidence on the effect of firm size, leverage, and asset mix towards tax avoidance activity.

Revenue from the sector of tax is the backbone for the government, so the taxpayer's honesty in carrying out its obligations is needed, especially in the self-assessment system adopted in Indonesia. Obedient or disobedient attitude is one of the attitudes of taxpayers that should be contemplated. Tax compliance is defined as a situation where the taxpayer meets all tax obligations and implements the rights of taxation. Tax compliance costs as tax transaction costs affect tax compliance (Prasetyo, 2008; cited from Surbakti, 2012). The higher tax compliance costs, the lower tax compliance, and vice versa. In general, the measurement of the tax compliance in satisfying the obligations in taxation is usually measured and compared to the tax savings, tax avoidance and tax evasion that are all aimed to minimize the tax burden (Zain, 2003; cited from Surbakti, 2012).

From an economic standpoint, tax avoidance, tax evasion, and tax flight have similar effects that they are equally an act of lowering the profits earned to subtract the amount of tax burden (Kirchler, Maciejovsky, \& Schneider, 2003 in Surbakti, 2012). However, in legal and moral sides, it shows that the terms have different meaning and level of justice, according to the results of a survey conducted by Kirchler, Maciejovsky, and Schneider (2003).

Tax avoidance is defined as an effort to reduce tax payments in a way that allowed by the law; that is, by utilizing the loopholes of existing regulations, and the definition is 
applied in this research. Tax avoidance is also associated with tax planning as the process of organizing the taxpayers' business so that the tax payable either income tax or other taxes are paid as lower as possible, as long as it is allowed by the provisions of the tax law (Pohan, 2013).

Many ways can be used to measure the activities of tax avoidance. Most proxies in the measurement of tax avoidance require data from the financial statements because the tax returns are not usually published and the access to the data is limited. The issue emphasized more nowadays is the development of research on tax avoidance, in particular of the measurements and the interpretation of the results when the sampled companies have different levels of accounting profit.

The evidence about the relation of ETRs to certain firm characteristics, such as firm size is inconsistent across studies. Firm size is the most controversial variable examined in prior ETR research. The empirical evidence is mixed. Siegfried (1972), Stickney and McGee (1982), and Porcano (1986) each finds a significantly negative association between ETRs and firm size. In contrast, Zimmerman (1983) and Omer, Molloy, and Ziebart (1993) document a significantly positive relationship between ETRs and firm size, while Jacob (1996), Gupta and Newberry (1997), and Mills, Erickson, and Maydew (1998) do not find any correlation. Differences in results have been attributed to sample selection (that is, industry composition - inclusion or exclusion of foreign firms), ETR definition, and the period under investigation (Rego, 2002).

There are two competing views about the association between ETRs and firm size: the political cost theory and the political power theory. Specifically, under the political cost theory, the higher visibility of larger and more prosperous firms causes them to become victims of greater regulatory actions by the government (Watts \& Zimmerman, 1986 as stated by Richardson \& Lanis, 2007). Large firms are subjected to increased government scrutiny and wealth transfers than smaller companies, which should translate into higher corporate tax burdens for corporations (Zimmerman, 1983). As taxes are one part of the total political costs developed by firms, this theory claims that larger firms have higher ETRs (Zimmerman, 1983 as cited in Richardson \& Lanis, 2007).

The alternative view under the political power theory is that larger firms have lower ETRs than smaller firms because larger firms have greater resources to (1) influence the political process, (2) develop expertise in tax planning, and (3) organize their activities in optimal tax saving ways (Siegfried, 1972; Rego, 2002). In short, if the ETRs of the company are high, it can be concluded that a company does not conduct any tax avoidance. According to Lestari (2010), firm size negatively affects the effective tax rates. Hanlon and Heitzman (2010) conclude that both ETRs and discretionary tax avoidance are proxies for measuring tax avoidance. However, if the effective tax rate goes up, then it makes discretionary tax avoidance goes down. Thus, the hypothesis to be tested regarding the relation between tax avoidance and firm size is:

$\mathrm{H}_{1}$ : Firm size has a positive influence towards tax avoidance.

Firms' Financing decisions could impact the tax avoidance activity because tax regulations normally allow differential tax treatment to the capital structure and asset mix decisions of firms (Gupta \& Newberry, 1997). For instance, consider the situation in which a firm relies more heavily on debt financing rather than equity financing to support its business operations. Given that interest expense is tax deductible while dividends are not, firms with higher leverage are expected to have lower ETRs. In other words, firms with higher leverage conduct more tax avoidance compared to those financed with equity. The financing decision of a company will affect ETRs because taxation has different treatments related to the capital structure (Gupta \& Newberry, 1997). Because ETR is also a proxy 
for measuring tax avoidance, the financing decision will also affect the existence of tax avoidance.

Companies can use the proportion of long-term debt due to the tax avoidance conducted as the companies that use debt financing will have lower ETRs than those that use equity financing. In other words, if a company wants to pay taxes in a small amount, the company should use debt financing. The size of the debts owed by the company to be very influential to the size of the tax paid. This is because the interest expense can be deducted in calculating the tax so that the debt can affect directly effective tax rate of the company. The company with higher debt will have an effective tax rate (ETR) lower because interest expenses will reduce the cost of the company's tax. Primordia (2015) reveals that leverage has no influence on ETR. Richardson and Lanis (2007) found that there is negative influence of leverage on ETR. Thus, the hypothesis to be tested is:

$\mathbf{H}_{2}$ : Leverage has a positive impact towards tax avoidance.

Firms' investment decisions in asset mix might also impact on ETRs and determine the tax avoidance activity conducted by the firms. As tax regulations usually permit taxpayers to write-off the cost of depreciable assets over shorter periods than their economic lives (Lestari, 2010; Surbakti, 2012), firms that are more capital-intensive (invest more in fixed assets) are expected to have lower ETRs (Stickney \& McGee, 1982). Gupta and Newberry (1997) provide evidence that firms with a larger proportion of fixed assets have lower ETRs due to tax incentives. If the effective tax rate is low, then the discretionary tax avoidance will rise, so the hypothesis to be tested is:

$\mathbf{H}_{3}$ : Capital Intensity has a positive influence towards tax avoidance.

Companies that conduct tax avoidance should certainly pay attention to the investment decisions that they do. If companies want to pay less tax, then it is better to use debt as a financing option and choose to invest in the form of inventory. By default, if the effective tax rate is lower, it is an indication of tax avoidance activity by the company that will make the discretionary tax avoidance to increase. This indicates the extent that inventory intensity is a substitute of capital intensity, inventory-intensity firms should possess higher ETRs (Zimmerman, 1983 as cited from Richardson \& Lanis, 2007). The higher the ETRs of the firm are, the lower the possibility of the firms to avoid taxes. So, the hypothesis to be tested is:

$\mathbf{H}_{4}$ : Inventory Intensity has a positive influence towards tax avoidance.

Return on Assets (ROA) is one of the ratios that measures the profitability of the company. According to Derazhid and Zhang (2003), the level of corporate profitability negatively affected the ETRs because the more efficient a company, the lesser the amount of taxes the company will pay so that the ETRs of the company will be smaller. This indicates the tax avoidance activity committed by the company, and it is consistent with the previous theoretical base in which the smaller ETRs, the greater the tax avoidance activity conducted by the company. Thus, the profitability of companies and tax avoidance will have a positive relationship. If the company wants to conduct tax avoidance, it requires a higher level of profitability which indicates the efficiency of the company, so that the company does not have to pay taxes in large numbers.

Lestari (2010) reveals that the business that has an excellent opportunity to invest would have higher ETRs. Conservatively, a significant investment will generate greater returns for the company and will certainly affect the burden of corporate taxes. The increasing of the companies' tax burden will affect the ETRs. Derazhid and Zhang (2003) and Surbakti (2012) also found that companies with a high market-to-book ratio have greater ETRs than the other companies. Therefore, the growth of the company has a 
negative relationship with tax avoidance. The company's growth has been linked to ETRs, in which to measure the tax avoidance activity in a company. Companies that have the intention to avoid taxes legally, of course, have to pay more attention to the growth of the company. Figure 1 illustrates the conceptual framework of the study.

\section{METHOD}

The population of the research comprises companies listed on the Indonesia Stock Exchange. Sample selection is performed with the certain criteria. Based on the sample criteria, this research obtained 158 firm-years observation for 4 year period $(2010-2013)$. The sample description of the study is illustrated in Table 2.1.

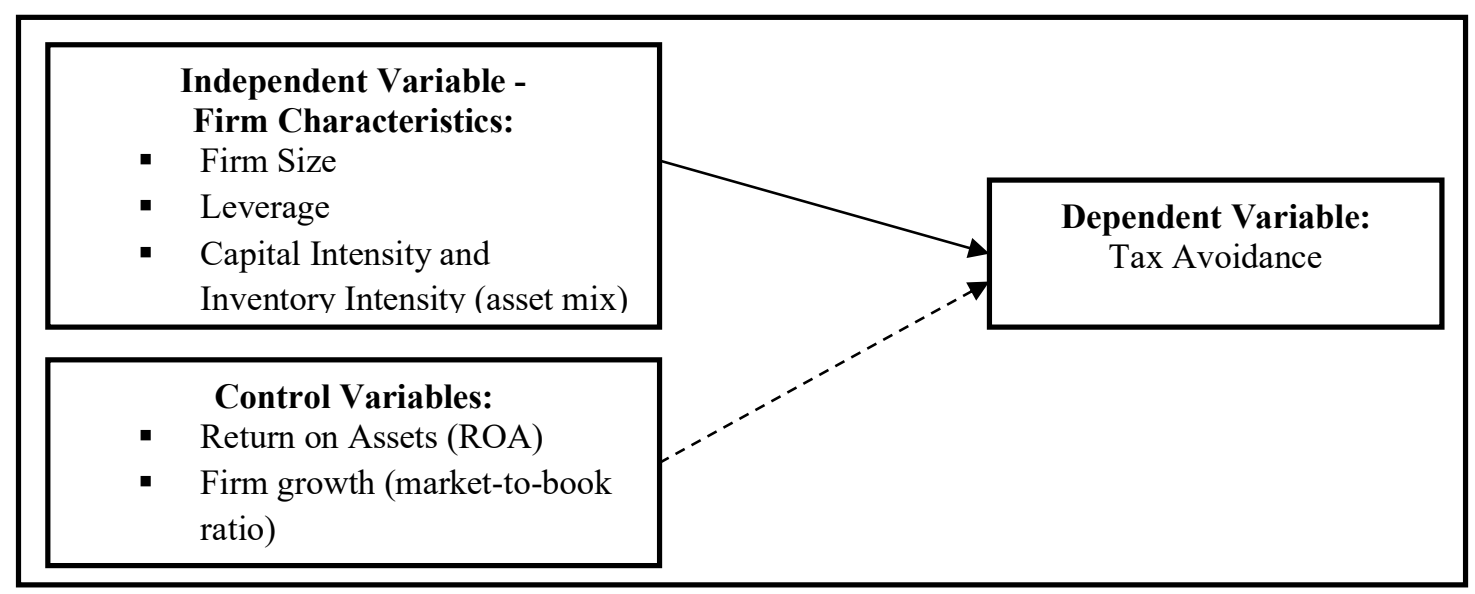

Figure 1.1. Conceptual Framework Of The Study

The sample is selected using purposive sampling that meets following criteria: 1). The companies do not include financial institutions since government regulation faced by these firms is likely to affect the results differently from other companies (Richardson \& Lanis, 2007). 2). The companies have no negative income, no tax refunds, and no loss carry forward (accumulated economic loss) since the results are distorted (Hanlon \& Heitzman, 2010; Zimmerman, 1983; Omer et al., 1993; Surbakti, 2012).

Table 2.1. Sample Description of the Study

\begin{tabular}{lc}
\hline \multicolumn{1}{c}{ Description } & Total \\
\hline Companies registered in Indonesia Stock Exchange for the period 2010-2013. & 502 \\
Criteria & $(83)$ \\
Companies that do not consistently listed in Indonesia Stock Exchange and do not & $(74)$ \\
issue annual report each year during 2010-2013. & $(10)$ \\
Companies that include in financial institutions. & $(93)$ \\
Companies that do not present the financial statement in Rupiah. & $(77)$ \\
Companies that do not have positive income consistently during 2010-2013. & $(94)$ \\
Companies that have tax refund during 2010-2013. & $\underline{(31)}$ \\
Companies that have loss carry forward during 2010-2013. & 40 \\
Data regarding the variables do not become available in the annual report & 160 \\
from 2010-2013 & $\underline{(2)}$ \\
Total companies used as samples for this research & 158 \\
Total firm-years observation (2010 - 2013) & \\
Outlier data & \\
\hline
\end{tabular}




\subsection{OPERATIONAL VARIABLES}

The dependent variable in this research is tax avoidance which is measured by the model developed by Desai and Dharmapala (2006):

Where: $B T_{i, t}=\beta_{1} T A_{i, t}+\varepsilon i$,

$\mathrm{BT}_{\mathrm{i}, \mathrm{t}} \quad$ : Book-tax gap for firm $i$ in year $t$

$\beta_{1} \mathrm{TA}_{\mathrm{i}, \mathrm{t}} \quad$ : Total accruals for firm $i$ in year $t$

$\varepsilon \mathrm{i}, \mathrm{t} \quad$ : The deviation in year $t$ from firm i's average residual $\mu_{\mathrm{i}}$

To calculate book-tax gap or book-tax differences, the research implements the empirical model of Manzon and Plesko (2002); the book-tax gap is operationalized as the difference between book income reported by companies to shareholders and tax income as declared by the tax regulations.

$$
B T=Y^{S}-\hat{Y}^{\top}
$$

Book-tax gap company $i$ year $t\left(\mathrm{BT}_{\mathrm{i}, \mathrm{t}}\right)$ is calculated by finding the difference between book income and tax income of firm $i$ in year $t$ divided by total assets in year $t-1$. Total accruals $\left(T A_{i, t}\right)$ is calculated by finding the difference between the net income of company $i$ in year $t$ minus cash flow from operations for firm $i$ in year $t$ (Surbakti, 2012) and divided by total assets in year t-1.

$$
\mathrm{TA}_{\mathrm{it}}=\mathrm{Nl}_{\mathrm{it}}-\mathrm{CFO}_{\mathrm{it}}
$$

The residual from regression (1) that cannot be explained by variations in total accruals can be interpreted as a measure of tax avoidance activity, so that there would only be one number that represents the value of the residual (error) needed in the regression results of equation (1) (Desai \& Dharmapala, 2006; Surbakti, 2012).

The independent variables consist of company size, leverage, capital intensity, and inventory intensity. Company size is a picture of the size of the company as indicated by the value of the total assets shown on the balance sheet. In this research, the researcher will use natural logarithm value of total assets of the company as the proxy of company size (Gupta \& Newberry, 1997). Leverage is included to proxy for firms' capital structure and is measured as the long-term debt divided by total assets (both at book values) (Gupta \& Newberry, 1997; Lanis \& Richardson, 2007). Capital intensity is one of the variables included in the study to proxy for firms' asset mix. It is measured as the net book value of property, plant, and equipment divided by total assets (Gupta \& Newberry, 1997; Lanis \& Richardson, 2007). Inventory intensity is also the variables included in the study to proxy for firms' asset mix. It is operationalized as inventory divided by total assets (both at book values) (Gupta \& Newberry, 1997; Lanis \& Richardson, 2007).

This research uses control variables that have been employed in the prior research as follows: Return on Asset (ROA) and Market to book ratio (M/B). ROA is used to control for changes in firms' operating results and measured as pre-tax income divided by total assets (Gupta \& Newberry, 1997). M/B is used to control the value of the company and measured as share price divided by book value (Lestari, 2010). 


\section{RESULTS AND DISCUSSION}

The coefficient of correlation $(R)$ test is used to measure the correlation between two or more independent variables and dependent variable. According to Table 3.1, the value of $R$ is 0.309 . It means that the correlation between the dependent variable and independent is weak because of the value less than 0.5. The coefficient of determination (Adjusted $R^{2}$ ) is used to measure how well the variation of independent variables can explain the variance of the dependent variable.

Table 3.1. Result Of Coefficient Of Correlation And Coefficient Of Determination Test

\begin{tabular}{ccccc}
\hline Model & $\mathrm{R}$ & $\begin{array}{c}\mathrm{R} \\
\text { Square }\end{array}$ & $\begin{array}{c}\text { Adjusted } \mathrm{R} \\
\text { Square }\end{array}$ & $\begin{array}{c}\text { Std. Error of the } \\
\text { Estimate }\end{array}$ \\
\hline 1 & $.309^{\mathrm{a}}$ & .063 & .060 & .134139149859 \\
\hline
\end{tabular}

According to Table 3.1, the value of Adjusted $R^{2}$ is 0.060 . It means that the variation of the dependent variable that can be explained by the variation of independent variables is only $6 \%$, while the remaining $94 \%$ is explained by other variables which are not included in the regression model on this research.

According to Table 3.2, SIZE variable recorded $t$ value of 1.310 and significance value of 0.192 . The significance value of $0.192>\alpha=0.05$, so it means that the result does not support $\mathrm{H}_{1}$. Thus, the size of a company has no effect on the level of tax avoidance. Though firm size is the most controversial variable examined in prior researches, it may still describe the tax avoidance activities related to the effective tax rate. While Hanlon and Heitzman (2010) conclude that both ETRs and discretionary tax avoidance are proxies for measuring tax avoidance, however, the researcher does not find any link between the size of the company and tax avoidance as measured by the discretionary tax avoidance through the book-tax differences in this research.

\begin{tabular}{|c|c|c|c|c|c|c|}
\hline \multirow[t]{2}{*}{ Model } & \multicolumn{2}{|c|}{$\begin{array}{l}\text { Unstandardized } \\
\text { Coefficients }\end{array}$} & \multirow{2}{*}{$\begin{array}{c}\begin{array}{c}\text { Standardized } \\
\text { Coefficients }\end{array} \\
\text { Beta }\end{array}$} & \multirow[t]{2}{*}{$t$} & \multirow[t]{2}{*}{ Sig. } & \multirow[t]{2}{*}{ Decision } \\
\hline & B & Std. Error & & & & \\
\hline (Constant) & -.116 & .093 & & -1.244 & .216 & \\
\hline SIZE & .008 & .006 & .115 & 1.310 & .192 & $\mathrm{H}_{1}$ Rejected \\
\hline LEV & .343 & .122 & .237 & 2.799 & .006 & $\mathrm{H}_{2}$ Accepted \\
\hline CAPINT & -.013 & .049 & -.022 & -.263 & .793 & $\mathrm{H}_{3}$ Rejected \\
\hline INVINT & -.074 & .071 & -.092 & -1.036 & .302 & $\mathrm{H}_{4}$ Rejected \\
\hline ROA & -.085 & .117 & -.058 & -.729 & .467 & \\
\hline $\mathrm{MB}$ & -3.299 & 18.575 & -.014 & -.178 & .859 & \\
\hline
\end{tabular}

Note: The level of significance is $5 \%$.

According to Table 3.2, SIZE variable recorded $t$ value of 1.310 and significance value of 0.192 . The significance value of $0.192>\alpha=0.05$, so it means that the result does not support $\mathrm{H}_{1}$. Thus, the size of a company has no effect on the level of tax avoidance. Though firm size is the most controversial variable examined in prior researches, it may still describe the tax avoidance activities related to the effective tax rate. While Hanlon and Heitzman (2010) conclude that both ETRs and discretionary tax avoidance are proxies for measuring tax avoidance, however, the researcher does not find any link between the size of the company and tax avoidance as measured by the discretionary tax avoidance through the book-tax differences in this research. The differences in result may lead to the sample selection (industry composition inclusion or exclusion of foreign firms), the measurement of the tax avoidance and the period under investigation. Thus, both theories describing the associations between ETRs and firm size which are the political power 
theory are rejected in this research. The hypothesis test regarding SIZE is not supported by the theories which stated that larger company has the resources to do tax planning and influence the political process so that the tax saving is optimal. Optimal tax savings result in less amount of tax expense paid, and it creates lower ETRs (lower ETRs means high discretionary tax avoidance).

LEV variable has a regression coefficient of 3.43 which shows positive influence. It also revealed $t$ value of 2.799 and significance value of 0.006 . The significance value of $0.006<\alpha=0.05$, so the result supports $\mathrm{H}_{2}$. It means that the leverage variable has a positive influence towards the level of tax avoidance. According to Gupta and Newberry (1997), the financing decision of a company will affect ETRs because taxation has different treatments related to the capital structure. Companies can use the proportion of long-term debt due to the tax avoidance as the interest expense can be used as a tax deduction in taxable income. In other words, firms with higher leverage may conduct more tax avoidance compared to those financed with equity. The companies that use debt financing will pay less tax and have lower ETRs than those that use equity financing, so it can be concluded that the discretionary tax avoidance will increase.

CAPINT variable demonstrated $t$ value of -0.263 and significance value of 0.793 . The significance value of $0.793>\alpha=0.05$, so it means that the result does not support $\mathrm{H}_{3}$. Thus, the capital intensity has no influence on the level of tax avoidance. INVINT variable also revealed $t$ value of -1.036 and significance value of 0.302 . The significance value of $0.302>\alpha=0.05$, so it means that the result does not support $\mathrm{H}_{4}$. Thus, the inventory intensity has no influence on the level of tax avoidance. As tax regulations usually permit taxpayers to write-off the cost of depreciable assets over shorter periods than their economic lives, firms that are more capital-intensive are expected to have lower ETRs and high discretionary tax avoidance (Stickney \& McGee, 1982). To the extent that inventory intensity is a substitute of capital intensity, inventory intensity firms should possess higher ETRs (Zimmerman, 1983 as cited from Richardson \& Lanis, 2007). The higher the ETRs of the firm are, the lower the possibility of the firms to avoid taxes. If companies want to pay less tax, then it is better to use debt as a financing option and choose to invest in the form of fixed assets rather than inventory.

This research indicates that firms that invest more either in fixed assets (capital intensive) or inventories (inventory intensity) have no significant effect towards the level of tax avoidance. The companies used as samples in this research might not certainly pay attention to the financing and investment decisions regarding the degree of tax avoidance activities conducted. They might not consider the options in optimizing the tax savings to avoid the corporate taxes paid each year. Therefore, financing and investment decisions cannot be used to determine the level of corporate tax avoidance in this research.

\section{CONCLUSIONS}

This research examined the influence of the firm characteristics to tax avoidance activities in the listed companies in Indonesia Stock Exchange from 2010-2013. This research used the proxies of firm size, leverage, capital intensity, inventory intensity as the firm characteristics and return on asset and market-to-book ratio as control variables. The samples of this research are 158 companies from all industries which are listed in Indonesia Stock Exchange during 2010-2013. The samples are selected by using purposive sampling method through several specific sample criteria. The empirical model used in this research is the replication model that was analyzed by Lestari (2010) and Surbakti (2012) by changing the dependent variables into tax avoidance activities as Hanlon and Heitzman (2010) stated that both ETRs and discretionary tax avoidance are proxies for measuring tax avoidance. 
Based on the results and discussion presented in the previous section, therefore, it can be concluded that 1). Company size has no influence towards tax avoidance activities. It is not proven that larger companies will have greater the ability to conduct tax avoidance activities through its tax planning. This result is not consistent with Siegfried (1972) in Gupta and Newberry (1997). 2). Leverage significantly has a positive influence towards tax avoidance activities. The higher the proportion of long-term debt used by the company in its financing decisions, the higher the level of tax avoidance that might be conducted. This result is inconsistent with Gupta and Newberry (1997), in Lestari (2010) and Surbakti (2012). 3). Capital intensity and inventory intensity have no influence towards tax avoidance activities. The difference of the tax treatments to the capital structure and asset mix decisions of firms does not affect the tax avoidance activities. The result is inconsistent with Gupta and Newberry (1997), Derashid and Zhang (2003), Richardson and Lanis (2005) and Surbakti (2012).

This research has a limitation which is this research only took 4 independent variables, which are firm size, leverage, capital intensity, and inventory intensity. There should be other variables considered in explaining the tax avoidance activities as the independent variables. The future research may be extended by observing more independent variables, so that the factors that can explain tax avoidance activities may be analyzed further.

\section{REFERENCES}

Constitution of the Republic of Indonesia Year 1945. Retrieved from https://www.kpi.go.id/download/regulasi/UUD\%201945.pdf

Derashid, C., \& Zhang, H. (2003). Effective Tax Rates and The "Industrial Policy" Hypothesis Evidence from Malaysia. Journal of International Accounting, Auditing, and Taxation, 45-62.

Desai, M. A., \& Dharmapala, D. (2006). Corporate Tax Avoidance and High- Powered Incentives. Journal of Financial Economics, 79, 145-179.

Leblang, S. (1998, July 20). International Double Nontaxation. Tax Notes International, 181-183.

Lestari, I. (2010). Pengaruh Karakteristik Perusahaan, Kepemilikan Manajerial, dan Reformasi perpajakan terhadap Tarif Pajak Efektif. Depok: Departemen Akuntansi Fakultas Ekonomi, Universitas Indonesia.

Mills, L., Erickson, M., \& Maydew, E. (1998). Investments in Tax Planning. The Journal of the American Taxation Association 20, 1-20.

Phillips, J. (2001). Corporate Tax Planning Effectiveness: The Role of Incentives. Working Paper University of Connecticut.

Pohan, C. A. (2013). Manajemen Perpajakan Strategi Perencanaan Pajak dan Bisnis. Jakarta: PT Gramedia Pustaka Utama.

Priantara, D. (2011). Kupas Tuntas Pengawasan, Pemeriksaan dan Penyidikan Pajak. Jakarta: PT Indeks.

Rego, S. (2002). Tax Avoidance Activities of U.S. Multinational Corporations. Working paper, available at http://www.ssrn.com.

Rismawati, D. (2013). Analisis Pengaruh Manajemen Laba, Profitabilitas dan Ukuran Perusahaan Terhadap Tarif Pajak Efektif Pada Perusahaan Manufaktur Di Bursa Efek Indonesia Periode Tahun 2005-2010. Yogyakarta: Fakultas Ekonomi Universitas Islam Indonesia.

Surbakti, T. A. (2012). Pengaruh Karakteristik Perusahaan dan Reformasi Perpajakan terhadap Penghindaran Pajak di Perusahaan Industri Manufaktur yang Terdaftar di Bursa Efek Indonesia Tahun 2008-2010. Depok: Fakultas Ekonomi Program Studi Akuntansi, Universitas Indonesia.

Wibowo, A. (2012). Faktor- Faktor yang Mempengaruhi Tarif Pajak Efektif (Studi pada Perusahaan Publik di Indonesia). Yogyakarta: Universitas Gadjah Mada. 